\title{
Método rápido de extração de DNA de bactérias
}

\author{
Daniel Dias Rosa
}

Universidade Estadual Paulista - UNESP, Faculdade de Ciências Agronômicas - FCA, Departamento de Produção Vegetal - Setor de Defesa Fitossanitária, CP 237, CEP: 18603-970 Botucatu, SP. Bolsista do CNPq - Brasil.

Autor para correspondência: Daniel Dias Rosa.danieldr@ hotmail.com

Data de chegada: 19/03/2007. Aceito para publicação em: 04/06/2008

\section{RESUMO}

Rosa, D.D. Método rápido de extração de DNA de bactérias. Summa Phytopathologica, v.34, n.3, p.259-261, 2008

Desenvolveu-se um método rápido para extração de DNA de bactérias, que ao contrário de outros métodos, não requer o uso de enzimas, como lisozima e proteinase $\mathrm{K}$, previamente, utilizadose o carbonato de silício (carborundum) como agente físico para efetuar a quebrar da parede celular da bactéria. Com este método conseguiu-se extrair DNA bacteriano num menor tempo, além de mais rápido, ele mostrou-se mais simples e econômico, quando comparado aos métodos convencionais. O DNA obtido pode ser utilizado para diversas finalidades relacionadas ao DNA de bactérias, obtendo-se uma quantidade razoável de DNA, que varia de $725 \mu \mathrm{g} / \mathrm{mL}$ a $1170 \mu \mathrm{g} / \mathrm{mL}$ por cada $0,1 \mathrm{~g}$ de célula bacteriana, com ótima qualidade.

Palavras-chave adicionais: PCR, gram-positiva, gram-negativa

\section{ABSTRACT}

Rosa, D.D. A fast DNA extraction method for bacteria. Summa Phytopathologica, v.34, n.3, p.259-261, 2008

A fast extraction method for bacteria DNA was developed. Unlike some other methods, the method does not require enzymes like lysozime and proteinase K. Carbonate silicate (carborundum) was used to break cell more efficiently. This method is fast, simple and more economic when compared to the previously report ones. The prepared DNA from bacteria has good quality and amount.

\section{Additional keywords: PCR, Gram-positive, Gram-negative}

A parede celular das células procarióticas sempre foi uma grande vantagem para esses organismos, pois ela apresenta diversas características como elasticidade, resistência a pressão, a altas temperaturas e a valores extremos de $\mathrm{pH}$. Tais características apresentam-se como um grande desafio para a biologia molecular (1). A coloração diferencial de Gram divide as bactérias em dois grupos: Gram-positivas e Gram-negativas, sendo o grupo das Gram negativas em maior número para a fitopatologia. A reação das bactérias à técnica de Gram é relacionada diretamente à composição química, estrutural e a permeabilidade da parede celular (3). A parede celular das bactérias Gram-positivas é constituída de uma camada espessa composta por peptídioglicano, responsável pela sua rigidez, já nas gram-negativas, a camada de peptidioglicano é mais fina, relativamente, que consequentemente confere uma maior fragilidade (3).

Essa característica faz com que a quebra da parede celular nas gram-positivas apresente maior dificuldade, que acaba por acarretar que as técnicas utilizadas para a quebra desta parede sejam muitas vezes trabalhosas, como a ruptura celular por sonicação, auxílio de enzimas (lisozima e proteinases) tornado as técnicas mais custosa e demoradas (2).

Atualmente existe a grande necessidade de se obter técnicas baratas, rápidas e eficientes para obtenção de DNA, visto que técnicas de identificação e detecção de patógenos por PCR vêm se popularizando cada vez mais. Este trabalho teve por objetivo avaliar um método de extração de DNA pela quebra da parede celular, utilizando-se da ação mecânica, causada por carbonato de silício (Carborundum), produto que apresenta granulométria entorno de $320 \mathrm{~mm}$ e é quimicamente inerte. Carborundum ou carbonato de silício é um produto abrasivo muito utilizado na fitopatologia para efetuar pequenos ferimentos, os quais viabilizam a infecção por vírus artificialmente.

Culturas bacterianas (Tabela 1) foram desenvolvidas em tubos do tipo Falcon ${ }^{\circledast}$, contendo $10 \mathrm{~mL}$ de meio de cultura Nutriente Líquido ( $1 \mathrm{~g}$ extrato de carne, $2 \mathrm{~g}$ extrato de levedura, $5 \mathrm{~g}$ peptona, $5 \mathrm{~g} \mathrm{NaCl}, 5 \mathrm{~g}$ dextrose, $1000 \mathrm{~mL}$ água destilada esterilizada) por 24 horas, a $28^{\circ} \mathrm{C}$, sobre agitação constante a $110 \mathrm{rpm}$. Após este período, as culturas foram centrifugadas a $5000 \mathrm{~g}$ por 30 minutos, descartando-se o sobrenadante e obtendo-se um precipitado, o qual foi ressuspendido em $1 \mathrm{~mL}$ de tampão de extração (20 mM Tris pH 7.5, 25 mM EDTA, $75 \mathrm{mM} \mathrm{NaCl}$ e $1 / 10$ volume de SDS $10 \%$ ) (4). O volume obtido foi transferido para um microtubo de $1,7 \mathrm{~mL}$, no qual foi acrescido de 0,2 gramas de carbonato de silício. Uma massa de 10 gramas de carbonato de silício foi previamente tratada com uma solução de $50 \mathrm{~mL}$ de ácido clorídrico $10 \mathrm{M}$, por 2 horas a temperatura de $30^{\circ} \mathrm{C}$, seguida de lavagem continua por 12 horas com água destilada, e posteriormente foi autoclavado a $120^{\circ} \mathrm{C}$ por 20 minutos e seco em estufa a $70^{\circ} \mathrm{C}$ por 24 horas. $\mathrm{O}$ microtubo contendo tampão de extração mais células bacterianas e o carbonato de silício foi agitado em aparelho tipo "vortex" a $2000 \mathrm{rpm}$ por 2 minutos, para romper a parede celular.

Os tubos foram incubação por 30 minutos, a $50^{\circ} \mathrm{C}$, após este período, acrescentou-se $2 / 3$ do volume de $\mathrm{NaCl} 5 \mathrm{Me}$, deixou-se, por 30 minutos, a $4^{\circ} \mathrm{C}$. Centrifugou-os por 10 minutos, a $10.000 \mathrm{~g}$, transferiu-se o sobrenadante para novos microtubos de $1,7 \mathrm{~mL}$ e 
Tabela 1. Bactérias utilizadas, valores de razão de absorbância e concentração do DNA.

\begin{tabular}{|c|c|c|c|c|c|}
\hline Amostra & $\begin{array}{l}\text { Isolados } \\
\text { bacterianos }\end{array}$ & Hospedeiro & $\begin{array}{l}\text { Reação de } \\
\text { Gram }\end{array}$ & Relação $\frac{\operatorname{Abs}_{260 \mathrm{~nm}}}{\operatorname{Abs}_{280 \mathrm{~nm}}}$ & $\begin{array}{l}\text { Concentração de } \\
\text { DNA }(\mathrm{mg} / \mathrm{mL})\end{array}$ \\
\hline 1 & Curtobacterium flaccumfaciens pv. flaccumfaciens & Feijão & + & 1,65 & 1170 \\
\hline 2 & Bacillus subtilis & -- & + & 1,55 & 1090 \\
\hline 3 & Xanthomonas axonopodis pv. vesicatoria & Tomateiro & - & 1,72 & 785 \\
\hline 4 & Xanthomonas campestris pv. passiflorae & Maracujazeiro & - & 1,73 & 1045 \\
\hline 5 & Xanthomonas vesicatoria & Tomateiro & - & 1,74 & 735 \\
\hline 6 & Escherichia coli & - & - & 1,64 & 725 \\
\hline 7 & Ralstonia solanacearum & Tomateiro & - & 1,78 & 1070 \\
\hline 8 & Clavibacter michiganensis subsp. michiganensis & Tomateiro & + & 1,67 & 1000 \\
\hline 9 & Xanthomonas campestris pv. campestris & Rabanete & - & 1,69 & 735 \\
\hline 10 & Acidovorax avenae subsp. citrulli & Meloeiro & - & 1,73 & 985 \\
\hline
\end{tabular}

adicionou-se 1 volume de clorofórmio, misturou-se vagarosamente e centrifulgou-se, por 10 minutos, a 10.000g. Transferiu-se a parte aquosa obtida para um novo microtubo de $1,7 \mathrm{~mL}$ e adicionou-se um volume de isopropanol e incubou-o em temperatura ambiente, por 5 minutos, procedendo em seguida um centrifugação durante 10 minutos, a $10.000 \mathrm{~g}$, sendo descartado o sobrenadante e o precipitado obtido (DNA) foi seco à temperatura ambiente, durante 5 minutos, e então adicionou-se $40 \mu \mathrm{L}$ de TE $\mathrm{pH}: 8,0+$ RNAse $10 \mu \mathrm{g} / \mu \mathrm{L}$ ao tubo e esse foi incubado por 60 minutos a $37^{\circ} \mathrm{C}$.

Após a extração, cada amostra de DNA teve sua concentração e pureza determinadas através das leituras de absorbância em $260 \mathrm{~nm}$ (Concentração do DNA em $\mu \mathrm{g} / \mathrm{mL}=$ Absx100x50) (4) e em $280 \mathrm{~nm}$ (quantificação de proteínas), no espectrofotômetro Ultrospec 3100 pro (Amershan Pharmacia Biotech). A razão entre as leituras em 260 nm e $280 \mathrm{~nm}$ foi utilizada como um indicativo da pureza do DNA obtido. A eletroforese para verificação da qualidade do DNA extraído foi realizada em gel de agarose $0,8 \%$. A esse gel foi aplicada uma amostra de cada um dos microtubos ( $3 \mu \mathrm{L}$ de água Milli- $\mathrm{Q}, 1 \mu \mathrm{L}$ de corante azul de bromofenol e $2 \mu \mathrm{L}$ da solução de DNA). Utilizou-se como padrão de comparação marcador Lambda $(\lambda)$, nas concentrações de 100 e $200 \mathrm{ng} / \mathrm{mL}$. Após 50 minutos em eletroforese a 90 voltz, o gel foi tratado com SYBR Safe ${ }^{\text {TM }}$ DNA Gel Stain (Invitrogen Corporation), conforme instrução do fabricante, e visualizado em um aparelho transluminador com luz UV.

Procedeu-se também uma reação de polimerase em cadeia (PCR) do gene ribossomal 16S dos DNAs extraídos, o qual foi amplificado utilizando-se oligonucleotídeos universais $(968$ forward: AAC GCG AAG AAC CTT AC; 1401 reverse: CGG TGT GTA CAA GAC CC) (4). A PCR foi realizada utilizando 1,0 ìl de DNA, 10,0 pmol de cada oligonucleotídeo, $10 \mathrm{mM}$ de dNTPs, $25 \mathrm{mM}$ de $\mathrm{MgCl}_{2}, 2,5 \mu \mathrm{l}$ de PCR Buffer 10x e $1 \mathrm{U}$ de Taq DNA Polimerase (Fermentas Life Science) para um volume final de $25 \mu \mathrm{l}$. A PCR foi realizada sob as seguintes condições: aquecimento inicial a $95^{\circ} \mathrm{C}$, por 5 minutos, seguido de 30 ciclos de desnaturação a $95^{\circ} \mathrm{C}$, por 30 segundos, anelamento do oligonucleotídeo a $57^{\circ} \mathrm{C}$, por 30 segundos, e alongamento a $72^{\circ} \mathrm{C}$, por 1 minuto. Um alongamento final de 5 minutos foi realizado após os ciclos. Os produtos amplificados, de aproximadamente $430 \mathrm{pb}$, foram examinados por eletroforese em gel de agarose a $1 \%$, com 5 Volts $/ \mathrm{cm}$, por 40 minutos. O gel foi corado com SYBR Safe ${ }^{\text {TM }}$ DNA Gel Stain (Invitrogen Corporation) e visualizado em um aparelho transluminador com luz UV.
Para verificar a degradação dos DNA extraído efetuou-se uma análise utilizando-se de gel de agarose $1 \%$ em eletroforese de campo pulsado, com 6 Volts/cm, ciclos de 25 por 35 , por 12 horas de corrida e visualizado em um aparelho transluminador com luz UV.

$\mathrm{Na}$ análise do DNA por espectrofotometria mostrou uma boa qualidade deste. Baseado nos valores da razão da absorbância de $260 \mathrm{~nm} / 280 \mathrm{~nm}$ mostrou que o DNA obtido estava de boa qualidade e com baixas concentrações de proteínas e de RNA (Tabela 1). A análise da extração do DNA em gel de agarose mostrou que a quantidade de quebra de DNA foi pequena, obtendo-se uma banda bem visível com pouco sinal de degradação (Figura 1A) e com boa quantidade extraída (Tabela 1) quando efetuada a análise quantitativa do DNA em relação ao marcador $\lambda$.

A quantificação por espectrofotometria mostrou que as concentrações dos DNAs extraídos variaram de $785 \mu \mathrm{g} / \mathrm{mL}$ a $1170 \mathrm{mg} /$ $\mathrm{mL}$ (Tabela 1). Na estimativa de rendimento da extração, relativa a uma massa de célula bacteriana de 0,1 grama, de células de $E$. coli, obteve-se uma concentração de $725 \mu \mathrm{g} / \mathrm{mL}$, que representa um rendimento de $29 \mu \mathrm{g}$ de DNA, ou seja, $290 \mu \mathrm{g}$ de DNA/g de célula de E. coli (Figura 1; Tabela 1A).

A análise para verificar a integridade do DNA utilizou-se a reação de PCR, com os oligonucleotídeos amplificadores da região do $16 \mathrm{~S}$ rDNA, obtendo-se um fragmento de 430 pares de base, esta amplificação mostrou que o DNA está integro, confiável para estudos utilizando-se de PCR a partir de DNA extraído por este método (Figura 1B).

Para comprovar a possibilidade da utilização do DNA extraído, por este método, para técnicas mais refinadas, como clonagem de grandes fragmentos de DNA em vetores do tipo BAC (Bacterial Artificial Chromosomal), efetuou-se a análise dos DNAs extraídos em eletroforese de campo pulsado por 11 horas, que mostrou uma fragmentação do DNA aceitável, apresentando fragmentos que variaram de 48.500 pares de base a 291.000 pares de base, mostrando assim que é viável a utilização desta técnica para construção de BACs (Dados não apresentados).

O método de extração utilizando carbonato de silício como ferramenta para romper a parede celular de bactérias gram-positivas e gram-negativas, visando a extração de DNA, mostrou-se eficiente, apresentando resultados satisfatórios quando comparados com os métodos descritos na literatura (2) e de baixo custo, quando comparado com os métodos tradicionais (2). 
A
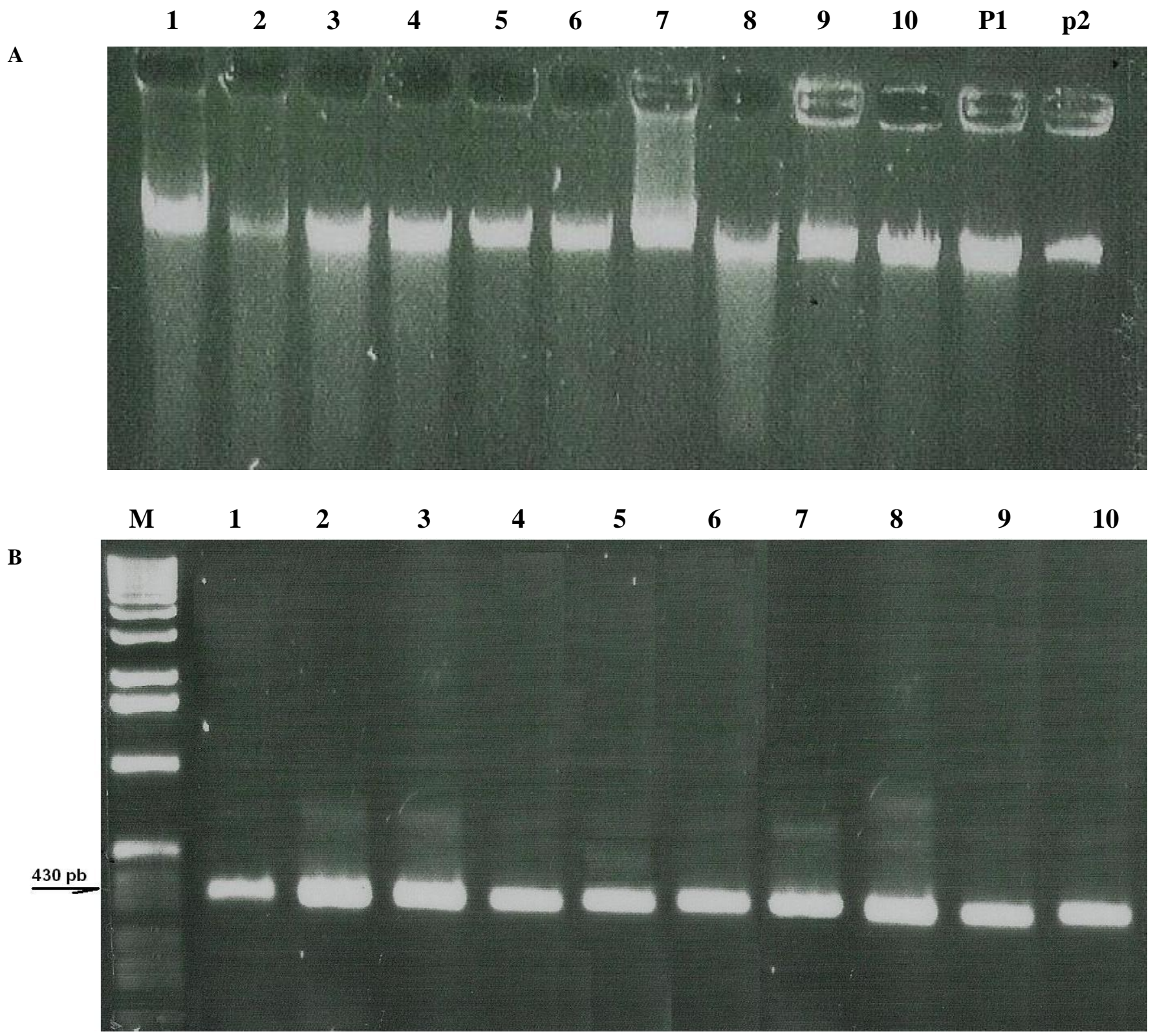

Figura 1. A) Quantificação do DNA em gel de agarose 0,8\%; P1 Marcador Lambda, $200 \mathrm{ng} / \mathrm{mL}$; P2. Marcador Lambda $100 \mathrm{ng} / \mathrm{mL} ; 1$. Curtobacterium flaccumfaciens pv. flaccumfaciens; 2. Bacillus subtilis; 3. Xanthomonas axonopodis pv. vesicatoria; 4. Xanthomonas campestris pv. passiflorae; 5. Xanthomonas vesicatoria; 6. Escherichia coli; 7. Ralstonia solanacearum; 8. Clavibacter michiganensis subsp. michiganensis; 9. Xanthomonas campestris pv. campestris; 10. Acidovorax avenae subsp. citrulli A1. B) Gel de agarose 1\%, produtos da reação de PCR com os oligonucleotídeos da região do gene $16 \mathrm{~S}$ rDNA, amplificando um produto de $430 \mathrm{pb}$, M. marcador de peso molecular $1 \mathrm{Kpb}$.

\section{REFERÊNCIAS BIBLIOGRÁFICAS}

1. Beveridge, T.J. Structures of gram-negative cell walls and their derived membrane vesicles. Journal of Bacteriology, Washington, v. 181, n. 16, p. 4725-4733, 1999.

2. Nogueira, C.A.M.; Momesso, C.A.S.; Machado, R.L.D.; Almeida, M.T.G. de.; Rossit, A.R.B. Desempenho de kits comerciais e protocolos laboratoriais para a extração de DNA genômico bacteriano. Revista Pana- mericana de Infectologia, São Paulo, v. 6, n. 2, p. 35-38, abr-jun, 2004.

3. Salton M.R.J. Studies of the bacterial cell wall. IV. The composition of the cell walls of some Gram-positive and Gram-negative bacteria. Biochim. et Biophysica Acta, Amsterdam, v. 10, n.4, p.512-523, 1953

4. Sambrook, J., Fritschi, E.F. e Maniatis, T. Molecular cloning: a laboratory manual. New York: Cold Spring Harbor Laboratory Press, 1989, p.720. 